\title{
Effect of maternal supplementation with seaweed extracts on growth performance and aspects of gastrointestinal health of newly weaned piglets after challenge with enterotoxigenic Escherichia coli K88
}

\author{
G. Heim ${ }^{1}$, T. Sweeney ${ }^{2}$, C. J. O'Shea ${ }^{1}$, D. N. Doyle ${ }^{1}$ and J. V. O'Doherty ${ }^{1 *}$ \\ ${ }^{1}$ School of Agriculture and Food Science, University College Dublin, Belfield, Dublin 4, Republic of Ireland \\ ${ }^{2}$ School of Veterinary Medicine, University College Dublin, Belfield, Dublin 4, Republic of Ireland \\ (Submitted 2 May 2014 - Final revision received 3 September 2014 - Accepted 7 September 2014 - First published online 27 October 2014)
}

Abstract

In the present study, a $2 \times 2$ factorial arrangement was conducted to investigate the effect of maternal supplementation with seaweed extracts (-SWE $v$. +SWE, $n$ 20) from day 83 of gestation until weaning (day 28) on post-weaning (PW) growth performance, faecal score, faecal enterotoxigenic Escherichia coli (ETEC) toxin quantification, intestinal histology and cytokine mRNA of unchallenged and ETEC-challenged pigs. Pigs were ETEC challenged on day 9 PW. There was a maternal treatment $\times$ challenge $(S W E \times$ ETEC) interaction effect on growth performance and faecal score $(P<0 \cdot 05)$. Pigs from SWE-supplemented sows and ETEC-challenged (SE) had higher average daily gain (ADG) during $0-13 \mathrm{~d}$ PW and reduced faecal score during $0-72 \mathrm{~h}$ post-challenge than those from basal-fed sows and ETEC-challenged (BE) $(P<0 \cdot 05)$. However, there was no difference between unchallenged pigs from the SWE-supplemented sows (SC) and basal-fed sows (BC) $(P>0 \cdot 10)$. Pigs from the SWE-supplemented sows had reduced heat-labile enterotoxin gene copy numbers than those from the basal-fed sows $(P<0 \cdot 05)$. Maternal SWE supplementation increased the villus height in the ileum of pigs $(P<0 \cdot 05)$. There was a SWE $\times$ ETEC interaction effect $(P<0.05)$ on $I L-6$ mRNA and a SWE $\times$ gastrointestinal (GI) region interaction effect $(P<0.05)$ on transforming growth factor- $\beta 1(T G F-\beta 1)$ and $T N F-\alpha$ mRNA. IL- 6 mRNA was down-regulated in SC pigs than BC pigs $(P<0 \cdot 05)$. However, there was no difference in $I L-6$ mRNA between SE and BE pigs. The mRNA of TGF- $\beta 1$ and $T N F-\alpha$ was down-regulated in the colon of pigs from the SWE-supplemented sows compared with those from the basal-fed sows $(P<0 \cdot 05)$. However, there was no difference in TGF- $\beta 1$ and TNF- $\alpha$ mRNA in the ileum between the pigs from the SWE-supplemented sows and basal-fed sows. In conclusion, maternal SWE supplementation improves ADG and the aspects of GI health of weaned pigs following an ETEC challenge.

Key words: Enterotoxigenic Escherichia coli K88 challenge: Inflammatory cytokines: Pig performance: Seaweed extracts

Enterotoxigenic Escherichia coli (ETEC) K88 is a major cause of diarrhoea in neonates and recently in weaned pigs ${ }^{(1,2)}$. It results in reduced growth rate, increased morbidity and mortality, and great economic loss in pig production worldwide $^{(3,4)}$. Post-weaning (PW) diarrhoea due to ETEC K88 generally occurs in pigs $3-10 \mathrm{~d} \mathrm{PW}^{(5,6)}$. ETEC K88 colonises in the small intestine and releases specific enterotoxins that impair intestinal barrier function, which indirectly induces fluid losses ${ }^{(4-6)}$. Several factors, such as stress of weaning, lack of milk and dietary changes, contribute to the severity of the disease. Furthermore, weaning is often associated with undesirable morphological and physiological changes in the gastrointestinal (GI) tract that is related to a reduced voluntary feed intake and, subsequently, susceptibility to intestinal health imbalance ${ }^{(7,8)}$. The ban on the inclusion of antibiotic growth promoters in weaning pig diets in Europe (European Community Regulation no. 1831/2003) has been associated with an increase in diarrhoea, weight loss and mortality due to $E$. coli in pigs $\mathrm{PW}^{(9)}$. Traditional measures to ameliorate or reduce PW disorders have centred on dietary manipulations $\mathrm{PW}^{(10-13)}$. However, recent research has indicated that maternal dietary supplementation with seaweed extracts (SWE) containing laminarin and fucoidan has beneficial effects on weaning-associated intestinal dysfunction

Abbreviations: ADFI, average daily feed intake; ADG, average daily gain; BC, pigs weaned from basal-fed sows and unchallenged; BE, pigs weaned from basal-fed sows and enterotoxigenic Escherichia coli K88-challenged on days 9 and 10 post-weaning; BW, body weight; cDNA, complementary DNA; CD, crypt depth; EAST1, enteroaggregative Escherichia coli heat-stable enterotoxin 1; ETEC, enterotoxigenic Escherichia coli; G:F, gain:feed ratio; GCN, gene copy number; GI, gastrointestinal; IFN- $\gamma$, interferon- $\gamma$; LT, heat-labile enterotoxin; qPCR, quantitative real-time PCR; PW, post-weaning; SAS, Statistical Analysis System; SC, pigs weaned from seaweed extract-supplemented sows and unchallenged; SE, pigs weaned from seaweed extract-supplemented sows and enterotoxigenic Escherichia coli K88-challenged on days 9 and 10 PW; STb, heat-stabile enterotoxin b; SWE, seaweed extracts; TGF- $\beta 1$, transforming growth factor- $\beta 1 ; \mathrm{VH}$, villus height.

* Corresponding author: J. V. O’Doherty, fax +353 17161103 , email john.vodoherty@ucd.ie 
and growth depression immediately after weaning ${ }^{(14)}$. Furthermore, pigs weaned from SWE-supplemented sows had a higher average daily gain (ADG) between days 0 and $21 \mathrm{PW}$ compared with those weaned from untreated sows ${ }^{(14)}$.

Experiments on the effect of maternal dietary supplementation with SWE on growth performance and indicators of GI health of weaned piglets after challenge with ETEC K88 PW are limited. The objective of the present study was to investigate the effect of maternal supplementation with SWE from day 83 of gestation until weaning (day 28) on pig growth performance, faecal score, ETEC K88 toxin quantification, intestinal architecture and gene expression profiles of cytokines of both unchallenged and ETEC K88-challenged weaned piglets. The hypothesis of the present study is that maternal supplementation with SWE would enhance the growth performance and improve the aspects of GI health and immune status of weaned piglets, making them more immune competent to deal with the PW adversities, represented in the present experiment by an ETEC K88 challenge.

\section{Materials and methods}

All procedures described in the present experiment were conducted under experimental license from the Irish Department of Health in accordance with the Cruelty to Animals Act 1876 and the European Communities (Amendments of the Cruelty to Animals Act, 1876) Regulations.

\section{Experimental design and animal diets - gestation and lactation periods}

A total of twenty cross-bred pregnant gilts (Large White $\times$ Landrace genetic lines, Hermitage) were assigned to one of two dietary treatments ( $n 10$ sows per treatment): basal gestation/lactation diet (T1) and basal gestation/lactation diet supplemented with $10 \cdot 0 \mathrm{~g}$ SWE/d (T2) from day 83 of gestation until weaning (day 28). The quantity of SWE (BioAtlantis Limited) used in the present study was based on previous work by Leonard et al. ${ }^{(14)}$. The SWE supplement $(10.0 \mathrm{~g} / \mathrm{d})$ contained laminarin $(1.0 \mathrm{~g})$, fucoidan $(0.8 \mathrm{~g})$ and ash $(8.2 \mathrm{~g})$, and was extracted from a Laminaria spp. according to the procedure described by Lynch et al. ${ }^{(15)}$. The gestation diet was formulated to contain $140 \mathrm{~g} / \mathrm{kg}$ of crude protein, $13.0 \mathrm{MJ} / \mathrm{kg}$ of digestible energy and $5.5 \mathrm{~g} / \mathrm{kg}$ of total lysine. The lactation diet was formulated to contain $190 \mathrm{~g} / \mathrm{kg}$ of crude protein, $14.5 \mathrm{MJ} / \mathrm{kg}$ of digestible energy and $10.0 \mathrm{~g} / \mathrm{kg}$ of total lysine. All amino acids requirements were met relative to lysine ${ }^{(16)}$. The ingredients and chemical analysis of the experimental diets are presented in Table 1.

\section{Animals and management}

Before day 83 of gestation, the gilts were housed in groups of ten. From day 83 until day 106 of gestation, they were housed individually in crates $(2.0 \times 0.6 \mathrm{~m})$ in the gestation house. In the farrowing house, the gilts were housed individually in farrowing pens $(2.2 \times 2.4 \mathrm{~m})$. The gestation house and farrowing room temperature was maintained at $20^{\circ} \mathrm{C}$ throughout the experiment. The experimental supplement (SWE) was topdressed on the gestation and lactation diets each morning (09.00 hours) to ensure consumption. The dams received specific amounts of feed in the following quantities: $2.5 \mathrm{~kg} / \mathrm{d}$ of gestation diet from day 83 until day 106 of gestation. They were fed $2 \mathrm{~kg} / \mathrm{d}$ of lactation diet from day 107 of gestation until the day of farrowing, and then the feed supply was increased by $1.0 \mathrm{~kg} / \mathrm{d}$ until day 3 post-farrowing and by $0.5 \mathrm{~kg} / \mathrm{d}$ until day 6 post-farrowing. Afterwards, the sows were allowed semi-ad libitum consumption of the lactation diet, which was adjusted for each sow depending on daily intake. The sows were fed in three equal meals provided at 09.00, 13.00 and 17.00 hours. The sows had ad libitum access to drinking-water throughout the experimental period.

\section{Farrowing and piglet management}

All farrowings were supervised. At parturition, each piglet (meat-line boars $\times$ Large White $\times$ Landrace genetic lines) was individually weighed and tagged. Between 6 and $12 \mathrm{~h}$ after the birth of the last piglet, litter size was adjusted by crossfostering piglets within dietary treatments to ensure that sows nursed a similar number of piglets ( $n 12$ piglets/sow), and this was maintained throughout the suckling period. The individual piglet body weight (BW) was recorded at birth, on day 7 and at weaning, and ADG calculated from these data. Piglets received an intramuscular injection of Fe-dextran (Ferdex 100; Medion Farma Jaya) on day 7 after birth. No creep feed was offered to the piglets throughout the lactation period.

\section{Post-weaning period - experimental design and animal management}

At weaning, a total of forty male pigs ( $n 2$ pigs/litter) with an average $\mathrm{BW}$ of $8.4(\mathrm{SD} 0 \cdot 14) \mathrm{kg}$ were selected. The selection was based on the average BW of the litter. The pigs were individually penned in a fully slated pen $(1.7 \mathrm{~m} \times 1.2 \mathrm{~m})$. The pigs were fed ad libitum with a standard diet for this age of pig until day 13 PW (Table 1). The diet was formulated to contain $210 \mathrm{~g} / \mathrm{kg}$ of crude protein, $15.0 \mathrm{MJ} / \mathrm{kg}$ of digestible energy and $14.5 \mathrm{~g} / \mathrm{kg}$ of ileal digestible lysine. Water was available from nipple drinkers at all times. Feed was available up to weighing of the pigs, and then weighed back for the purpose of calculating feed intake. Representative feed sample was taken on day 0 (day of weaning) for chemical analysis. The ingredient composition and chemical analysis of the PW diet are presented in Table 1 .

House temperature was maintained at $30^{\circ} \mathrm{C}$ during the first $7 \mathrm{~d}$ and then reduced to $28^{\circ} \mathrm{C}$ until day $13 \mathrm{PW}$. On days 9 and $10 \mathrm{PW}$, twenty pigs (ten pigs weaned from the basal-fed sows and ten pigs weaned from the SWE-supplemented sows) were housed in unsanitised rooms and orally challenged with ETEC K88 to induce PW diarrhoea and the other twenty pigs were housed in sanitised rooms and received only PBS (Oxoid), resulting in four groups: pigs weaned from the basal-fed sows and unchallenged (control pigs, $n 10$; BC); pigs weaned from the basal-fed sows and ETEC k88-challenged on days 9 and $10 \mathrm{PW}$ ( $n$ 10; BE); pigs 
Table 1. Ingredients and chemical analysis of the experimental diets

( $\mathrm{g} / \mathrm{kg}$, unless otherwise indicated)

\begin{tabular}{|c|c|c|c|}
\hline & Gestation diet ${ }^{*}$ & Lactation diet ${ }^{*}$ & Post-weaning diet \\
\hline \multicolumn{4}{|l|}{ Ingredients } \\
\hline Wheat & $343 \cdot 8$ & 318.8 & $380 \cdot 0$ \\
\hline Barley & $300 \cdot 0$ & $300 \cdot 0$ & 233.5 \\
\hline Soyabean meal & $67 \cdot 0$ & $182 \cdot 0$ & $170 \cdot 0$ \\
\hline Full-fat soyabean & & & $120 \cdot 0$ \\
\hline Dried maize distillers' grains & $60 \cdot 0$ & $100 \cdot 0$ & \\
\hline Soya hulls & $70 \cdot 0$ & & \\
\hline Beet pulp & $100 \cdot 0$ & & \\
\hline Whey powder & & & $50 \cdot 0$ \\
\hline Soya oil & $30 \cdot 0$ & $70 \cdot 0$ & $10 \cdot 0$ \\
\hline Vitamins and minerals $† \ddagger$ & 3.0 & 2.5 & 3.0 \\
\hline Salt & $3 \cdot 0$ & $5 \cdot 0$ & $3 \cdot 0$ \\
\hline Dicalcium phosphate & $11 \cdot 2$ & $12 \cdot 0$ & $12 \cdot 5$ \\
\hline Limestone & $12 \cdot 0$ & $12 \cdot 0$ & $11 \cdot 0$ \\
\hline Lys-HCl & & $2 \cdot 0$ & $4 \cdot 0$ \\
\hline DL-Met & & 1.0 & 1.5 \\
\hline L-Thr & & 1.0 & 1.5 \\
\hline \multicolumn{4}{|l|}{ Chemical analysis } \\
\hline DM & 870.9 & $873 \cdot 2$ & $866 \cdot 1$ \\
\hline Crude protein $(\mathrm{N} \times 6.25)$ & $140 \cdot 0$ & $190 \cdot 0$ & $210 \cdot 6$ \\
\hline Gross energy $(\mathrm{MJ} / \mathrm{kg})$ & 16.9 & $17 \cdot 1$ & $17 \cdot 1$ \\
\hline Ash & $55 \cdot 2$ & $57 \cdot 1$ & 48.4 \\
\hline Neutral-detergent fibre & - & - & $115 \cdot 1$ \\
\hline $\mathrm{DE}(\mathrm{MJ} / \mathrm{kg}) \S$ & 13.5 & 14.5 & 14.5 \\
\hline Lys§ & 5.5 & $10 \cdot 0$ & 14.5 \\
\hline Met and Cys§ & 3.3 & 6.0 & 8.4 \\
\hline Thr§ & 3.85 & $7 \cdot 0$ & $9 \cdot 1$ \\
\hline Trp§ & 1.0 & 1.8 & 2.5 \\
\hline $\mathrm{Ca \S}$ & $8 \cdot 7$ & $9 \cdot 3$ & 9.5 \\
\hline$P \S$ & $5 \cdot 0$ & $5 \cdot 2$ & $6 \cdot 1$ \\
\hline
\end{tabular}

$\mathrm{DE}$, digestible energy.

* T1, basal diet; T2, basal diet supplemented with $10.0 \mathrm{~g}$ seaweed extract/d.

† Gilt/sow diet provided (per kg diet): $250 \mathrm{mg}$ choline chloride; $140 \mathrm{mg} \mathrm{Fe;} 120 \mathrm{mg} \mathrm{Zn}$ as $\mathrm{ZnO} ; 67 \mathrm{mg}$ $\alpha$-tocopherol; $47 \mathrm{mg} \mathrm{Mn}$ as $\mathrm{MnO} ; 25 \mathrm{mg} \mathrm{Cu}$ as $\mathrm{CuSO}_{4} ; 12 \mathrm{mg}$ nicotinic acid; $10 \mathrm{mg}$ pantothenic acid; $4 \mathrm{mg}$ phytylmenaquinone; $2 \mathrm{mg}$ riboflavin; $2 \mathrm{mg}$ thiamin; $1.8 \mathrm{mg}$ retinol; $0.6 \mathrm{mg}$ iodine as calcium iodate on a calcium sulphate/calcium carbonate carrier; $0.3 \mathrm{mg}$ Se as sodium selenite; $0.025 \mathrm{mg}$ cholecalciferol; $0.01 \mathrm{mg}$ cyanocobalamin; $0.015 \mathrm{mg}$ pyridoxine.

$\mp$ Weaner diet provided (per kg diet): $100 \mathrm{mg} \mathrm{Zn}$ as $\mathrm{ZnO} ; 40 \mathrm{mg} \alpha$-tocopherol; $25 \mathrm{mg} \mathrm{Mn}$ as $\mathrm{MnO} ; 25 \mathrm{mg}$ $\mathrm{Cu}$ as $\mathrm{CuSO}_{4} ; 0.3 \mathrm{mg}$ retinol; $0.2 \mathrm{mg}$ iodine as calcium iodate on a calcium sulphate/calcium carbonate carrier; $0.3 \mathrm{mg}$ Se as sodium selenite; $0.05 \mathrm{mg}$ cholecalciferol.

$\S$ Calculated from amino acid and DE values of ingredients ${ }^{(46)}$

weaned from the SWE-supplemented sows and unchallenged ( $n$ 10; SC); pigs weaned from the SWE-supplemented sows and ETEC k88-challenged on days 9 and 10 PW ( $n$ 10; SE). Each treatment was housed in separated rooms, to avoid cross-contamination between the treatments. The unsanitised rooms were uncleaned following a previous batch of weaned pigs, while the sanitised rooms were cleaned and disinfected following the previous batch of weaned pigs. The pigs were weighed at weaning (day 0), day 9 (before the ETEC K88 challenge) and at the end of the experiment (day 13). The pigs were humanely killed on day 13 by lethal injection with pentobarbital sodium (Euthatal Solution, $200 \mathrm{mg} / \mathrm{ml}$; Merial Animal Health Limited) at a rate of $0.71 \mathrm{ml} / \mathrm{kg} \mathrm{BW}$ to the cranial vena cava, and the entire GI tract was immediately removed.

Enterotoxigenic Escherichia coli K88 challenge - bacterial culture, oral challenge, health status and sample collection

The ETEC K88 strain (Abbotstown, O149:K91:K88), obtained from Animal Health and Veterinary Laboratories Agency
(AHVLA, Addlestone, Surrey, UK), was grown in Luria-Bertani broth. The pathogen was derived from clinical cases of PW colibacillosis and characterised as having the required virulence factors to induce PW colibacillosis. The expanded culture of ETEC K88, approximately $1 \times 10^{8}$ colony-forming units $/ \mathrm{ml}$, was further prepared for oral dosing as described by Zhang et $a l{ }^{(17)}$. The suspension was calculated on the basis of optical density established by serial dilution before bacterial cell count. Pigs were not tested for susceptibility to these adhesion factors, but were from a herd where persistent PW ETEC K88 shedding was recorded. At 08.00 hours on days 9 and $10 \mathrm{PW}$, the pigs ( $n$ 20) were orally given a dose of $10 \mathrm{ml}$ PBS containing approximately $1 \times 10^{8}$ colony-forming units of ETEC K88 using a syringe attached to a polyethylene tube held in the back of the oral cavity. The unchallenged control pigs received $10 \mathrm{ml}$ of sterilised PBS only. The bacterial solution and PBS was slowly dribbled into the pig's throat so that the swallowing reflex was triggered and passage of the inoculant into the lungs was minimised.

The pigs were checked for diarrhoea to evaluate their status before and after challenging with ETEC K88. 
Severity of diarrhoea was characterised by using the following faecal consistency score system described by Pierce et al. ${ }^{(18)}$ : (1) hard firm faeces; (2) slightly soft faeces; (3) soft, partially formed faeces; (4) loose, semi-liquid faeces (mild diarrhoea); (5) watery, mucous-like faeces (severe diarrhoea). Faecal scores were taken before the ETEC challenge (day 9, $0 \mathrm{~h}$ ) and every $12 \mathrm{~h}$ after the challenge until day 13 ( $72 \mathrm{~h})$. Faecal consistency score was performed by two trained personnel with no prior knowledge of the sow's dietary treatment.

Fresh faecal samples were collected directly from the rectum of each pig at 0,24 and $48 \mathrm{~h}$ after ETEC K88 challenge and stored at $-20^{\circ} \mathrm{C}$ for quantification of ETEC K88 toxin genes (heat-labile enterotoxin - LT, heat-stabile enterotoxin b - STb and enteroaggregative E. coli heat-stable enterotoxin 1 - EAST1). Diarrhoea caused by ETEC K88 is attributable to the action of one or more enterotoxins produced by the bacteria that have colonised the small intestine, such as $L T$, $S T b$ and EAST1 ${ }^{(4,19)}$.

\section{Chemical analysis}

The feed samples (gestation, lactation and PW diets) were analysed for N, DM, ash, gross energy and neutral-detergent fibre). The feed samples were milled through a hammer mill provided with a $1 \mathrm{~mm}$ screen (Christy and Norris Hammer Mill; Christy Turner Limited). The nutrient contents (N, DM, ash, gross energy and neutral-detergent fibre) in the diets were determined as described by Heim et al. ${ }^{(13)}$. The total laminarin content of the SWE was determined using a Megazyme kit (Megazyme International Ireland Limited). Fucoidan levels were determined using the method described by Usov et al. ${ }^{(20)}$.

\section{Collection of tissue samples}

Immediately after slaughter, the entire digestive tract was removed by blunt dissection, and sections of the duodenum $(10 \mathrm{~cm}$ from the stomach), the jejunum $(60 \mathrm{~cm}$ from the stomach) and the ileum $(15 \mathrm{~cm}$ from the caecum) were excised and fixed in 10\% phosphate-buffered formalin for villus height $(\mathrm{VH})$ and crypt depth (CD) measurements. Ileum and colon tissues (second loop of the proximal colon) were excised, emptied by dissecting them along the mesentery and rinsed using sterile PBS (Oxoid). Tissue sections of $1 \mathrm{~cm}^{2}$, which was stripped of the overlying smooth muscle, were cut from each tissue and stored in $15 \mathrm{ml} \mathrm{RNAlater}{ }^{\circledR}$ solution (Applied Biosystems) overnight at $4^{\circ} \mathrm{C}$. RNAlater ${ }^{\circledR}$ was then removed before storing the samples at $-80^{\circ} \mathrm{C}$.

\section{Microbiology - DNA extraction and quantitative $P C R$ from faecal samples}

Microbial genomic DNA was extracted from faecal samples using a QIAamp DNA stool kit (Qiagen) in accordance with the manufacturer's instructions. Quantity and quality of DNA was assessed using a Nanodrop ND1000 spectrophotometer (Thermo Scientific). Standard curves were generated as described by O'Shea et al. ${ }^{(21)}$. Briefly, genomic DNA from all faecal samples was pooled and amplified through routine PCR using ETEC K88 toxin primers (LT, STb and EAST1). The ETEC K88 toxin primers are presented in Table 2. All primers were designed using Primer Express $^{\mathrm{TM}}$ software (Applied Biosystems) and synthesised by MWG Biotech. Serial dilutions of these amplicons served to generate standard curves using quantitative real-time PCR (qPCR - ABI 7500 Real-Time PCR System; Applied Biosystems Limited), allowing estimations of absolute quantification based on gene copy number $(\mathrm{GCN})^{(22)}$. qPCR were performed in a final reaction volume of $20 \mu \mathrm{l}$ containing $3 \mu \mathrm{l}$ of template DNA, $1 \mu \mathrm{l}$ of forward (100 pM) and $1 \mu \mathrm{l}$ of reverse primers (100 pM), $10 \mu \mathrm{l}$ SYBR Green PCR Master Mix (Applied Biosystems) and $5 \mu \mathrm{l}$ nuclease-free water. The thermal cycling conditions involved an initial denaturation step at $95^{\circ} \mathrm{C}$ for $10 \mathrm{~min}$ followed by forty cycles of $95^{\circ} \mathrm{C}$ for $15 \mathrm{~s}$ and $65^{\circ} \mathrm{C}$ for $1 \mathrm{~min}$. Dissociation analyses of the $\mathrm{qPCR}$ product were performed to confirm the specificity of the resulting qPCR products. All samples were prepared in duplicate. The mean cycle threshold $\left(C_{\mathrm{t}}\right)$ values of duplicates of each sample were used for calculations.

\section{Duodenal, jejunal and ileal morphology}

The preserved segments (duodenum, jejunum and ileum) were prepared using standard paraffin-embedding techniques. The samples were sectioned at $5 \mu \mathrm{m}$ thickness and stained with haemotoxylin and eosin ${ }^{(23)}$. Measurements of fifteen well-orientated and intact villi and crypts were taken for each segment. The $\mathrm{VH}$ and the CD were measured as described by Heim et al. ${ }^{(13)}$. The results are expressed as mean $\mathrm{VH}$ or $\mathrm{CD}$ in $\mu \mathrm{m}$. The VH:CD ratio was calculated.

\section{RNA extraction, complementary DNA synthesis and quantitative real-time $P C R$}

RNA was extracted from approximately $50 \mathrm{mg}$ of tissue samples using the GenElute Mammalian Total RNA Miniprep Kit (Sigma-Aldrich Corporation), according to the manufacturer's instructions. Total RNA was quantified using $1.5 \mu \mathrm{l}$ of total RNA on a NanoDrop Spectrophotometer ND1000 (Thermo Fisher Scientific, Inc.), and samples with a 260:280 ratio $\geq 2 \cdot 0$ were considered suitable for complementary DNA (cDNA) synthesis. Total RNA integrity (i.e. quality and quantity) was assessed by analysing $1 \mu \mathrm{l}$ of total RNA using the Agilent 2100 Bioanalyser version A.02.12 (Agilent Technologies, Inc.) using RNA Nano LabChips ${ }^{\circledR}$ (Caliper Technologies Corporation). cDNA synthesis was performed using $1 \mu \mathrm{g}$ of total RNA and oligo $(\mathrm{dT})_{20}$ primers in a final reaction volume of $20 \mu \mathrm{l}$ using Superscript ${ }^{\mathrm{TM}}$ III First-Strand synthesis kit (Invitrogen Life Technologies) following the manufacturer's instructions. The final reaction volume of $20 \mu \mathrm{l}$ was then adjusted to $250 \mu \mathrm{l}$ using nuclease-free water. All primers for the selected cytokine genes $I L-1, I L-2, I L-6, I L-8, I L-10$, $I L-12 A$ (p35), IL-17, TNF- $\alpha$, interferon- $\gamma(I F N-\gamma)$, transforming growth factor- $\beta 1$ (TGF- $\beta 1$ ), forkhead box P3 (FOXP3) were designed using Primer Express ${ }^{\mathrm{TM}}$ (PE Applied Biosystems) and synthesised by MWG Biotech. Primer sequences are 
Table 2. Porcine oligonucleotide primers used for real-time PCR

\begin{tabular}{|c|c|c|c|}
\hline Genes & Accession no. & Primer $\left(5^{\prime} \rightarrow 3^{\prime}\right)$ & Product length $(\mathrm{bp})$ \\
\hline \multirow[t]{2}{*}{$L T^{*}$} & \multirow[t]{2}{*}{. } & F: GCTACAAATGCCTATGCATCTACACA & \multirow[t]{2}{*}{275} \\
\hline & & R: CATGCTCCAGCAGTACCATCTCTAAC & \\
\hline$S T b \dagger$ & . & F: ACGGCGTTACTATCCTGTCTATGTGC & 125 \\
\hline \multirow[t]{2}{*}{ EAST1† } & . & F: TGCCATCAACACAGTATATCC & \multirow[t]{2}{*}{109} \\
\hline & & R: GCGAGTGACGGCTTTGT & \\
\hline \multirow[t]{2}{*}{$I L-1$} & NM_214029.1 & F: CAGCCAACGGGAAGATTCTG & \multirow[t]{2}{*}{77} \\
\hline & & R: AATGGCTTCCAGGTCGTCAT & \\
\hline \multirow[t]{2}{*}{$I L-2$} & NM_213861.1 & F: TAACСТCААСТССТGCСАСАATG & \multirow[t]{2}{*}{87} \\
\hline & & R: GTGCACCGTTTGCCATGA & \\
\hline \multirow[t]{2}{*}{ IL-6 } & NM_214399.1 & F: GACAAAGCCACCACCCCTAA & \multirow[t]{2}{*}{69} \\
\hline & & R: CTCGTTCTGTGACTGCAGCTTATC & \\
\hline \multirow[t]{2}{*}{ IL-8 } & NM_213867.1 & F: TGCACTTACTCTTGCCAGAACTG & \multirow[t]{2}{*}{82} \\
\hline & & R: CAAACTGGCTGTTGCCTTCTT & \\
\hline \multirow[t]{2}{*}{ IL-10 } & NM_214041.1 & F: GCCTTCGGCCCAGTGAA & \multirow[t]{2}{*}{71} \\
\hline & & R: AGAGACCCGGTCAGCAACAA & \\
\hline \multirow[t]{2}{*}{ IL-12A (p35) } & NM_213993.1 & F: CGTGCCTCGGGCAATTATA & \multirow[t]{2}{*}{68} \\
\hline & & R: CGCAGGTGAGGTCGCTAGTT & \\
\hline \multirow[t]{2}{*}{ IL-17 } & NM_001005729.1 & F: CAAGCGGTGGCGTTTTGCCT & \multirow[t]{2}{*}{57} \\
\hline & & R: GTCTCCGTCGGGGATGGGCT & \\
\hline \multirow[t]{2}{*}{$I F N-\gamma$} & NM_213948.1 & F: TCTAACCTAAGAAAGCGGAAGAGAA & \multirow[t]{2}{*}{81} \\
\hline & & R: TTGCAGGCAGGATGACAATTA & \\
\hline \multirow[t]{2}{*}{$T G F-\beta 1$} & NM_214015.1 & F: AGGGCTACCATGCCAATTTCT & \multirow[t]{2}{*}{101} \\
\hline & & R: CGGGTTGTGCTGGTTGTACA & \\
\hline \multirow[t]{2}{*}{$T N F-\alpha$} & NM_214022.1 & F: TGGCCCCTTGAGCATCA & \multirow[t]{2}{*}{68} \\
\hline & & R: CGGGCTTATCTGAGGTTTGAGA & \\
\hline \multirow[t]{2}{*}{ FOXP3 } & NM_001128438.1 & F: GTGGTGCAGTCTCTGGAACAAC & \multirow[t]{2}{*}{68} \\
\hline & & R: AGGTGGGCCTGCATAGCA & \\
\hline \multirow[t]{2}{*}{ PPIA } & NM_214353.1 & F: CGGGTCCTGGCATCTTGT & 75 \\
\hline & & R: TGGCAGTGCAAATGAAAAACTG & \\
\hline$B M$ & NM_213978.1 & F: CGGAAAGCCAAATTACCTGAAC & 83 \\
\hline & & R: TCTCCCCGTTTTTCAGCAAAT & \\
\hline
\end{tabular}

$L T$, heat-labile enterotoxin; $\mathrm{F}$, forward; $\mathrm{R}$, reverse; $S T b$, heat-stabile enterotoxin $\mathrm{b}$; EAST1, enteroaggregative Escherichia coli heat-stable enterotoxin 1 ; IFN- $\gamma$, interferon- $\gamma$; TGF- $\beta 1$, transforming growth factor- $\beta$; FOXP3, forkhead box P3; $P P I A$, peptidylprolyl isomerase A; $B M, \beta 2$-microglobulin.

* Zhang et al. ${ }^{(47)}$

† Metzler-Zebeli et al. ${ }^{(48)}$.

presented in Table 2. A panel of pro- and anti-inflammatory cytokines chosen was selected based on previous work by Walsh et al. ${ }^{(12)}$ and Leonard et al. ${ }^{(24)}$. The efficiencies of all primer sets were established using a semi-log curve of quantity $v$. control, of two-fold serial dilutions of cDNA as reported previously by Smith et al. ${ }^{(25)}$. The following two porcine reference genes were used as described previously by Ryan et $a{ }^{(26)}$ : $\beta 2$-microglobulin $(B M)$ and peptidylprolyl isomerase A (PPIA). qPCR was then carried out on cDNA using the ABI PRISM 7500 Fast Sequence Detection System for ninety-sixwell plates (Applied Biosystems). All samples were prepared in duplicate using the SYBR Green Fast PCR Master Mix (Applied Biosystems), cDNA as the template and specific primers for the genes selected. For each reaction, $5 \mu \mathrm{l}$ cDNA, $1.2 \mu \mathrm{l}$ forward and reverse primer mix (300 nm), $3.8 \mu \mathrm{l}$ nuclease-free water and $10 \mu \mathrm{l}$ Fast SYBR Green PCR Master Mix (PE Applied Biosystems) were added and made up to a final volume of $20 \mu \mathrm{l}$. The two-step PCR programme was as follows: $95^{\circ} \mathrm{C}$ for $10 \mathrm{~min}$ for one cycle, followed by $95^{\circ} \mathrm{C}$ for $15 \mathrm{~s}$ and $60^{\circ} \mathrm{C}$ for $1 \mathrm{~min}$ for forty cycles.

The mean $C_{\mathrm{t}}$ values of duplicates of each sample were used for calculations. Normalised relative quantities were obtained using qbase PLUS software (Biogazelle).

\section{Statistical analysis}

All data were analysed using the general linear model procedure of Statistical Analysis System (SAS; SAS Institute, Inc. $)^{(27)}$. All data were initially checked for normality using the univariate procedure in $\mathrm{SAS}^{(27)}$. For pig performance (BW, ADG, average daily feed intake (ADFI) and gain:feed ratio $(G: F)$ ), faecal score, ETEC K88 toxin gene expression and cytokine gene expression, the data were analysed by repeated-measures analysis using the PROC MIXED procedure of SAS ${ }^{(28)}$. The model included the effects of sow dietary treatment, ETEC K88 challenge and time, and the associated two-way and three-way interactions. Gene copy estimates of ETEC K88 toxins were log-transformed before statistical analysis. The statistical model used for cytokine gene expression included both GI sites (ileum $v$. colon), sow dietary treatment and ETEC K88 challenge and the associated two-way and three-way interactions. Small intestinal morphology data were analysed as a $2 \times 2$ factorial arrangement, with the pig as the experimental unit. The statistical model used included the effects of sow dietary treatment and ETEC K88 challenge and the associated interaction. Contrast statements were used to compare (1) basal-fed sows $v$. SWE-supplemented sows (lactation effect), (2) non-challenge $v$. ETEC K88 
challenge PW effect and (3) the interaction between the lactation effect and the PW effect. The sow data for the lactation period were analysed as a complete randomised block design, with the sow as the experimental unit. The pdiff function of SAS was used to separate means.

All data presented in the tables are expressed as least-square means with their standard errors of the mean. The probability level that denotes significance is $P<0 \cdot 05$.

\section{Results}

\section{Lactation period}

Gilts offered the SWE extracts had a longer gestation period than basal-fed gilts $(114.5 v .113 .5 \mathrm{~d}$, SEM $=0.27, P<0.05)$. Litter size (14.4 (SD 0.72) piglets) and number of live-born piglets (12.9 (SD 0.62)) were not influenced by sow dietary treatments $(P>0 \cdot 10)$. Sow dietary treatment had no effect on piglet BW at birth (1.76 (SD 0.66) kg), on day 7 after birth (2.70 (SD $0.09) \mathrm{kg}$ ) and at weaning (8.33 (SD 0.22$) \mathrm{kg}$ ), and had no effect on ADG from birth to day 7 of lactation ( 0.189 (SD $0 \cdot 010) \mathrm{kg} / \mathrm{d})$ and from birth to weaning $(0 \cdot 240(\mathrm{sD} 0 \cdot 069) \mathrm{kg} / \mathrm{d})$ $(P>0$ 10). Piglets suckling SWE-supplemented sows had higher ADG compared with those suckling basal-fed sows $(0 \cdot 249 v \cdot 0 \cdot 230 \mathrm{~kg} / \mathrm{d} ; \mathrm{SEM}=0.064 ; P<0 \cdot 05)$ from day 8 of lactation to weaning.

\section{Post-weaning period}

Growth performance. The effect of sow dietary treatment and ETEC K88 challenge on pig growth performance PW is presented in Table 3. No difference was recorded in pig BW at weaning (day 0) among the dietary treatments ( $P>0 \cdot 10)$. There was a sow dietary treatment $\times$ ETEC K88 challenge $($ SWE $\times$ ETEC) interaction effect on pig BW (days 9 and 13), ADG (days 0-9 and 9-13) and G:F (days 0-9) $(P<0.05)$. The BE pigs had a decreased BW, ADG and G:F compared with the SE pigs $(P<0 \cdot 05)$. However, there was no difference in BW, ADG and G:F between the BC and SC pigs $(P>0 \cdot 10)$. There was a SWE $\times$ ETEC $\times$ time interaction effect on pig ADFI $(P<0 \cdot 05)$. The BE pigs had a decreased ADFI compared with $\mathrm{BC}$ pigs during $0-9$ and $9-13 \mathrm{~d}(P<0.05)$. However, there was no difference in ADFI between the SC and SE pigs during 9-13d ( $P>0 \cdot 10)$, and the SE pigs had decreased ADFI compared with the SC pigs during 0-9 d $(P<0.05)$.

Faecal score. The effect of sow dietary treatment and ETEC K88 challenge on pig faecal score from $0 \mathrm{~h}$ (immediately before the ETEC K88 challenge) to $72 \mathrm{~h}$ post-challenge is presented in Fig. 1. There was a SWE $\times$ ETEC $\times$ time interaction effect on pig faecal score from 0 to $72 \mathrm{~h}$ post-challenge $(P<0.05)$. The BE pigs had higher faecal score at $0,12,36$, 48,60 and $72 \mathrm{~h}$ post-challenge compared with the SE pigs $(P<0.05)$. However, there was no difference in faecal score at 0,12 and $36 \mathrm{~h}$ post-challenge between the $\mathrm{BC}$ and $\mathrm{SC}$ pigs $(P>0 \cdot 10)$; at $24 \mathrm{~h}$, the BC pigs had lower faecal score compared with the SC pigs, and at 48,60 and $72 \mathrm{~h}$ postchallenge, the $\mathrm{BC}$ pigs had higher faecal score compared with the SC pigs $(P<0 \cdot 05)$. 


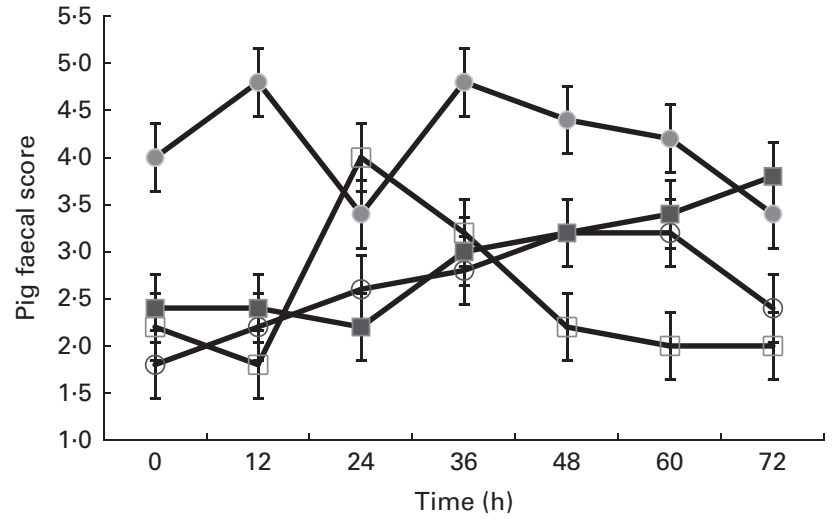

Fig. 1. Differences in pig faecal score over time at 0 (immediately before the enterotoxigenic Escherichia coli (ETEC) K88 challenge), 12, 24, 36, 48, 60 and $72 \mathrm{~h}$ post-challenge. Values are means, with their standard errors represented by vertical bars. BC, pigs weaned from basal-fed sows and unchallenged (-SWE - ETEC K88; - - ); BE, pigs weaned from basal-fed sows and ETEC K88-challenged on days 9 and 10 post-weaning (PW) (-SWE + ETEC K88; --); SC, pigs weaned from SWE-supplemented sows and unchallenged (+SWE - ETEC K88; - - ); SE, pigs weaned from SWE-supplemented sows and ETEC K88-challenged on days 9 and 10 PW (+SWE +ETEC K88; - - $)$. There was an effect detected for the SWE $\times$ ETEC $\times$ time interaction $(P<0.001)$.

Gene expression of enterotoxigenic Escherichia coli $K 88$ toxins in the faeces. The effect of sow dietary treatment and ETEC K88 challenge on EAST1, LT and STb log GCN/g faeces at 0, 24 and $48 \mathrm{~h}$ post-challenge is presented in Table 4 . There was a time effect on LT, EAST1 and STb log GCN/g faeces $(P<0.05)$. At $24 \mathrm{~h}$ post-challenge, $L T$ and $S T b$ $\log \mathrm{GCN} / \mathrm{g}$ faeces were decreased compared with the faecal collection time point at 0 and $48 \mathrm{~h}$ post-challenge $(P<0.05)$. In contrast, EAST1 $\log \mathrm{GCN} / \mathrm{g}$ faeces was increased at $24 \mathrm{~h}$ compared with the 0 and $48 \mathrm{~h}$ time points $(P<0.05)$. The ETEC K88 challenge increased EAST1 and STb log GCN/g faeces $(P<0 \cdot 05)$. Pigs weaned from the SWE-supplemented sows had reduced LT $\log \mathrm{GCN} / \mathrm{g}$ faeces compared with those weaned from the basal-fed sows $(P<0 \cdot 05)$.

Small-intestinal morphology. The effect of sow dietary treatment and ETEC K88 challenge on VH, CD and the $\mathrm{VH}: \mathrm{CD}$ ratio in the duodenum, jejunum and ileum of pigs on day $13 \mathrm{PW}$ is shown in Table 5. Pigs challenged with ETEC K88 tended to have a reduced VH:CD ratio in the duodenum $(P=0.064)$ and deeper $\mathrm{CD}$ in the jejunum $(P<0.05)$ compared with unchallenged pigs. Pigs weaned from the SWE-supplemented sows had longer $\mathrm{VH}$ and higher VH:CD ratio in the ileum compared with those weaned from the basal-fed sows $(P<0.05)$.

Cytokine gene expression. The effect of sow dietary treatment and ETEC K88 challenge on the expression of pro- and anti-inflammatory cytokines in the ileum and in the colon tissues is presented in Table 6 . There was a SWE $\times$ ETEC interaction effect on the gene expression of the cytokine IL- 6 $(P<0.05)$. The gene expression of $I L-6$ was down-regulated in the ileum and colon tissues of SC pigs compared with $\mathrm{BC}$ pigs $(P<0.05)$. However, there was no difference in the gene expression of $I L-6$ in the ileum and colon tissues between the SE and BE pigs $(P>0 \cdot 10)$. There was an ETEC K88 $\times$ GI region interaction effect on the gene expression of the cytokines $I L-6, I L-10, I L-12 A$ (p35) and TGF- $\beta 1$ $(P<0.05)$. The gene expression of $I L-10$ and $I L-12 A$ (p35) was up-regulated in the ileum of ETEC K88-challenged pigs compared with their expression in the ileum of unchallenged pigs $(P<0.05)$. However, there was no difference in the gene expression of $I L-1 O$ and $I L-12 A$ (p35) in the colon between the ETEC K88-challenged and unchallenged pigs $(P>0 \cdot 10)$. The gene expression of $I L-6$ and $T G F-\beta 1$ was down-regulated in the colon of ETEC K88-challenged pigs compared with their expression in the colon of unchallenged pigs $(P<0 \cdot 05)$. However, there was no difference in the gene expression of $I L-6$ and TGF- $\beta 1$ in the ileum between the ETEC K88-challenged and unchallenged pigs $(P>0 \cdot 10)$. There was a SWE $\times$ GI region interaction effect on the gene expression of the cytokines $I L-8, T G F-\beta 1$ and $T N F-\alpha(P<0 \cdot 05)$. The gene expression of $I L-8$ was up-regulated in the ileum of pigs weaned from the SWE-supplemented sows compared with its expression in the ileum of pigs weaned from the basal-fed sows $(P<0.05)$. However, there was no difference in the gene expression of $I L-8$ in the colon between the pigs weaned from the SWEsupplemented sows and those weaned from the basal-fed sows $(P>0 \cdot 10)$. The gene expression of TGF- $\beta 1$ and $T N F-\alpha$ was down-regulated in the colon of pigs weaned from the SWE-supplemented sows compared with their expression in the colon of pigs weaned from the basal-fed sows $(P<0.05)$ However, there was no difference in the gene expression of $T G F-\beta 1$ and $T N F-\alpha$ in the ileum between the pigs weaned from the SWE-supplemented sows and those weaned from the basal-fed sows $(P>0 \cdot 10)$. The gene expression of $I F N-\gamma$ tended to be up-regulated in the ileum and colon tissues of pigs weaned from the SWE-supplemented sows compared with those weaned from the basal-fed sows $(P=0 \cdot 09)$.

Table 4. Effect of sow dietary treatment on enterotoxigenic Escherichia coli (ETEC) K88 toxin log gene copy number/g faeces following an ETEC K88 challenge*

(Least-squares mean values with their standard errors, $n 10$ pigs/treatment group)

\begin{tabular}{|c|c|c|c|c|c|c|c|c|c|c|c|}
\hline \multirow[b]{2}{*}{ Items } & \multicolumn{2}{|c|}{ SWE } & \multicolumn{2}{|c|}{ ETEC } & \multicolumn{3}{|c|}{ Time (h) } & \multirow[b]{2}{*}{ SEM } & \multicolumn{3}{|c|}{$P \dagger$} \\
\hline & Yes & No & Yes & No & 0 & 24 & 48 & & SWE & ETEC & Time \\
\hline$L T$ & 4.78 & 5.72 & 5.52 & 4.98 & $6 \cdot 31$ & $2 \cdot 39$ & 7.04 & 0.31 & 0.022 & 0.190 & $<0.001$ \\
\hline$S T b$ & 6.48 & $6 \cdot 50$ & $6 \cdot 81$ & $6 \cdot 18$ & $6 \cdot 86$ & 5.89 & 6.72 & 0.19 & 0.944 & 0.016 & 0.005 \\
\hline EAST1 & 6.44 & 6.47 & 6.66 & $6 \cdot 24$ & $6 \cdot 13$ & $6 \cdot 86$ & $6 \cdot 36$ & 0.12 & 0.854 & 0.009 & $<0.001$ \\
\hline
\end{tabular}

SWE, seaweed extracts; $L T$, heat-labile enterotoxin; $S T b$, heat-stabile enterotoxin b; EAST1, enteroaggregative E. coli heat-stable enterotoxin 1.

${ }^{*}$ ETEC K88 oral challenge: days 9 and 10 post-weaning

$\dagger$ There was no effect detected for the SWE $\times$ ETEC interaction $(P>0 \cdot 10)$ or the SWE $\times$ ETEC $\times$ time interaction $(P>0 \cdot 10)$. 
Table 5. Effect of sow dietary treatment and enterotoxigenic Escherichia coli (ETEC) K88 challenge* on small-intestinal morphology of pigs on day 13 post-weaning

(Least-squares mean values with their standard errors, $n 10$ pigs/treatment group)

\begin{tabular}{|c|c|c|c|c|c|c|c|}
\hline \multirow[b]{2}{*}{ Items } & \multicolumn{2}{|c|}{ SWE } & \multicolumn{2}{|c|}{ ETEC } & \multirow[b]{2}{*}{ SEM } & \multicolumn{2}{|c|}{$P$ (effect) $\dagger$} \\
\hline & No & Yes & No & Yes & & SWE & ETEC \\
\hline \multicolumn{8}{|l|}{ Duodenum } \\
\hline $\mathrm{VH}(\mu \mathrm{m})$ & 150 & 155 & 164 & 141 & $11 \cdot 2$ & 0.730 & 0.149 \\
\hline $\mathrm{CD}(\mu \mathrm{m})$ & 129 & 133 & 128 & 134 & $5 \cdot 8$ & 0.705 & 0.529 \\
\hline VH:CD & 1.2 & $1 \cdot 2$ & 1.3 & $1 \cdot 1$ & 0.1 & 0.985 & 0.064 \\
\hline \multicolumn{8}{|l|}{ Jejunum } \\
\hline $\mathrm{VH}(\mu \mathrm{m})$ & 112 & 116 & 108 & 120 & $9 \cdot 3$ & 0.784 & 0.378 \\
\hline $\mathrm{CD}(\mu \mathrm{m})$ & 111 & 116 & 107 & 120 & 4.5 & 0.377 & 0.054 \\
\hline $\mathrm{VH}: \mathrm{CD}$ & 1.0 & 1.0 & 1.0 & 1.0 & 0.1 & 0.858 & 0.828 \\
\hline \multicolumn{8}{|l|}{ Ileum } \\
\hline $\mathrm{VH}(\mu \mathrm{m})$ & 80 & 115 & 102 & 93 & $9 \cdot 0$ & 0.008 & 0.474 \\
\hline $\mathrm{CD}(\mu \mathrm{m})$ & 109 & 106 & 103 & 113 & $6 \cdot 5$ & 0.752 & 0.288 \\
\hline VH:CD & 0.8 & $1 \cdot 2$ & $1 \cdot 1$ & 0.9 & 0.1 & 0.025 & 0.326 \\
\hline
\end{tabular}

SWE, seaweed extracts; VH, villus height; $C D$, crypt depth.

${ }^{*}$ ETEC K88 oral challenge: days 9 and 10 post-weaning.

† There was no effect detected for the SWE $\times$ K88 interaction $(P>0 \cdot 10)$.

The gene expression of $I L-10$ was up-regulated in the ileum and colon tissues of pigs challenged with ETEC K88 compared with unchallenged pigs $(P<0 \cdot 05)$. No effect was observed on the gene expression of the cytokines FOXP3, IL-1, IL-17 and $I L-2$ in the ileum and colon tissues $(P>0 \cdot 10)$

\section{Discussion}

The objective of the present experiment was to evaluate the effects of maternal dietary supplementation with SWE from day 83 of gestation until weaning on weaned piglet growth performance, faecal score, faecal ETEC K88 toxin quantification, intestinal histology and gene expression profiles of pro- and anti-inflammatory cytokines following an ETEC K88 challenge on days 9 and 10 PW. It was hypothesised that maternal supplementation with SWE would improve the growth performance and indicators of GI health of weaned pigs after an ETEC K88 challenge PW. The positive response observed in pigs weaned from SWE-supplemented sows on growth performance, faecal score, intestinal morphology and immunological response PW compared with those weaned from basal-fed sows supports the hypothesis.

\section{Lactation period}

The SWE supplement $(10.0 \mathrm{~g} / \mathrm{d})$ contained laminarin $(1.0 \mathrm{~g})$, fucoidan $(0.8 \mathrm{~g})$ and ash $(8.2 \mathrm{~g})$. It is speculated that this level of ash in the SWE supplement would have no impact on sow performance as it made up only a very small proportion of total ash intake. The present data indicate that SWE supplementation from day 83 of gestation increased the gestation length of the gilt. Their gestation length was prolonged by $1 \mathrm{~d}$ compared with the basal-fed gilts. In the swine species, the gestation length is an average of $114 \mathrm{~d}$, with $85 \%$ of farrowing concentrating between 114 and $116 \mathrm{~d}$ of gestation ${ }^{(29)}$. However, this increase in gestation length did not influence piglet BW at birth. There was also no effect of maternal dietary treatment on piglet BW on day 7 of age and at weaning. Chau et al. ${ }^{(30)}$ observed no effect of sow dietary supplementation with yeast-derived $\beta$-glucans in the growth rate of piglets. Similarly Leonard et al. ${ }^{(24)}$ also reported no effect of sow supplementation with a similar SWE from day 107 of gestation to weaning (26d) on piglet growth during the lactation period.

\section{Post-weaning}

The SE pigs had higher BW, ADG, ADFI and G:F compared with the BE pigs. However, there was no difference in BW, ADG, ADFI and G:F between the $\mathrm{BC}$ and SC pigs. The SE pigs had a lower faecal score at $0,12,36,48,60$ and $72 \mathrm{~h}$ post-challenge compared with the $\mathrm{BE}$ pigs. However, there was no difference in faecal score at 0,12 and $36 \mathrm{~h}$ postchallenge between the BC and SC pigs. At 48, 60 and $72 \mathrm{~h}$ post-challenge, the SC pigs had a lower faecal score compared with the BC pigs. The lack of a negative effect of ETEC K88 challenge on the growth performance and faecal score of pigs weaned from the SWE-supplemented sows could be due to a number of reasons. First, it may be attributed to the immunomodulatory effects of SWE in enhancing cellular and humoral immune function, as well as suppressing the $E$. coli population $^{(24)}$. Leonard et al. ${ }^{(24)}$ demonstrated that sow supplementation with SWE reduced colonic E. coli numbers in piglets at weaning. A suppressed colonic E. coli population may ultimately alleviate the incidence and severity of PW diarrhoea $^{(31)}$. The present data demonstrated that maternal supplementation with SWE down-regulated the gene expression of a panel of pro-inflammatory cytokines (IL-6, TGF- $\beta$ and $T N F-\alpha$ ) in the ileum and colon tissues. It has been shown that less activation of the immune system during the weaning period could result in an improvement in growth performance ${ }^{(32)}$. Second, it may be attributable to an increase in E. coli-phagocytising effect (not analysed in the present experiment). According to Leonard et al. ${ }^{(33)}$, piglets suckling SWE-supplemented sows had a greater percentage of E. coli phagocytising leucocytes and a reduced percentage of E. coli-phagocytising lymphocytes at weaning, indicating an enhancement of immune function against presenting pathogens. Third, it may be attributable to the positive changes in the intestinal architecture (increased $\mathrm{VH}$ and $\mathrm{VH}: \mathrm{CD}$ ratio in the ileum). A reduction in $\mathrm{VH}$ and the $\mathrm{VH}$ :CD ratio has been associated with poor performance and increased incidences of scouring in pigs challenged with ETEC ${ }^{(34)}$. Villi are critical components of the digestive tract and their geometry provides an indicator of the absorptive capacity of the small intestine ${ }^{(7)}$. Turnover of the intestinal epithelium reflects a dynamic equilibrium between the production of enterocytes in the crypts and their subsequent desquamation from the villus ${ }^{(7)}$. The $\mathrm{VH}: \mathrm{CD}$ ratio is a useful criterion for assessing intestinal health and function ${ }^{(7,35)}$. The results obtained from the present study showed that pigs weaned from the SWE-supplemented sows had longer villi and a higher $\mathrm{VH}$ :CD ratio in the ileum. Furthermore, sow dietary supplementation with SWE clearly prevented the damage to intestinal morphology, otherwise 
caused by ETEC K88 infection alone, which is in accordance with the improved performance and lower incidence of diarrhoea in pigs weaned from those sows.

Diarrhoea caused by ETEC K88 is attributable to the action of one or more enterotoxins produced by the bacteria that have colonised the small intestine, such as EAST1, either as the only toxin gene or with the classic toxins associated with this pathotype, $L T$ and $S T b$, to impair the intestinal barrier function, which indirectly induces fluid losses ${ }^{(4,36,37)}$. In the present experiment, the ETEC K88 challenge increased the gene expression of EAST1 and STb. Interestingly, in the present experiment, pigs weaned from the SWE-supplemented sows had reduced $L T \log \mathrm{GCN} / \mathrm{g}$ faeces compared with those weaned from the basal-fed sows. According to Fairbrother et al. ${ }^{(4)}$, ETEC K88 is a major cause of diarrhoea in pigs during days 3-10 PW. The pathogen colonises in the small intestine, releasing specific enterotoxins that induce fluid $\operatorname{losses}^{(4-6)}$. An in vivo study on gnotobiotic piglets revealed that $L T$ is the major virulence factor of K88 ETEC, because it enhances bacterial colonisation of the intestine ${ }^{(38)}$. It may also be postulated from the present study that the reduction of ETEC K88 toxin $L T$ in pigs weaned from the SWEsupplemented sows may be associated with the reduced faecal score of pigs weaned from those sows. However, a potential effect of ETEC was already present before the ETEC challenge begun, as evidenced by the GCN of ETEC toxins. Despite the presence of high GCN of ETEC toxins before the challenge, faecal scores were low, except for the BE pigs. Therefore, caution should be exercised when using the presence of toxin genes in the faeces as an indicator of ill health and diarrhoea in weaned pigs.

Maternal supplementation with SWE from day 83 of gestation and throughout the lactation period enhanced the immune response of weaned pigs reflected by a downregulation of the gene expression of the pro-inflammatory cytokines $I L-6, T G F-\beta$ and $T N F-\alpha$. If maternal supplementation with SWE suppresses the secretion of pro-inflammatory cytokines, then less activation of the immune system during the weaning period would be achieved, which could result in an improvement in growth performance ${ }^{(32)}$. The gene expression of $I L-10$ and $I L-12 A$ (p35) (pro-inflammatory cytokines) was up-regulated in the ileum of ETEC K88-challenged pigs compared with their expression in the ileum of unchallenged pigs. According to Girard et al ${ }^{(39)}$, the first step in the pathogenesis of ETEC is adhesion to the ileal epithelium with the subsequent production of enterotoxins inducing intestinal acute diarrhoea and inflammation. Then, E. coli can be probably engulfed by antigen-presenting cells, e.g. macrophages, and evokes different courses of inflammation $^{(40)}$. An interesting observation is that the gene expression of cytokines classically involved in ETEC challenge (i.e. IL-1, IL-8 and TNF- $\alpha$ ) was low or null in the present study. Perhaps some early sign may have already been passed in the small intestine on day 4 post-challenge. During ETEC infection, it is imperative to generate an adequate inflammatory response against the pathogen, accompanied by efficient regulation, in order to achieve protection without damaging the host tissues ${ }^{(41)}$. In the present study, the gene expression 
of $I L-8$ was up-regulated in the ileum of pigs weaned from the SWE-supplemented sows compared with its expression in the ileum of pigs weaned from the basal-fed sows. The gene expression of $I F N-\gamma$ tended to be up-regulated in the ileum and colon tissues of pigs weaned from the SWE-supplemented sows compared with those weaned from the basal-fed sows. The tissue collection was carried out on day 13 PW, the period during which PW diarrhoea due to ETEC K88 generally occurs in pigs ${ }^{(5,6)}$. Leonard et al. ${ }^{(24)}$ reported that maternal supplementation with SWE enhanced the expression of a pro-inflammatory cytokine $(T N F-\alpha)$ in the ileum after an ex vivo lipopolysaccharide challenge at weaning. Rice et al. $^{(42)}$ also reported an increase of a pro-inflammatory cytokine (IL-G), in the serum, after oral administration of $\beta$-glucan. According to Xiao et al. ${ }^{(43)}$, monocytes/macrophages are the major effectors of innate immunity, functioning as the first barrier of natural defence. $\beta$-Glucans can stimulate macrophages, neutrophils and natural killer cells, and could promote T-cellspecific responses by the induction of cytokines such as $I F N-\gamma$, $I L-8$ and $I L-12$ from macrophages, neutrophils and natural killer cells ${ }^{(43-45)}$. Rice et al. ${ }^{(42)}$ demonstrated that laminarin delivered orally can be internalised by intestinal epithelial cells and gut-associated lymphoid cells in the murine model. However, the possibility of mammary uptake of laminarin or fucoidan or both and subsequent introduction to the GI tract of suckling piglets was not examined in the present experiment. Furthermore, in the present experiment, the up-regulation of pro-inflammatory cytokines ( $I L-8$ and $I F N-\gamma$ ) by maternal supplementation with SWE did not affect growth performance.

\section{Conclusion}

The data reported in the present study indicate that maternal supplementation with SWE from day 83 of gestation to weaning prevented the negative effect on growth performance and diarrhoea induced by the ETEC K88 challenge. It does so by improving the function of intestinal health, offsetting or preventing impaired intestinal morphology, reducing faecal ETEC K88 toxin (LT) and down-regulating a panel of inflammatory cytokines. Collectively, these results indicated an important immunomodulatory role of maternal SWE supplementation on piglet immune function at weaning that may help alleviate the negative impact of a disease challenge at this period. These results provide new insights into the protective activity of maternal SWE supplementation, making it a good alternative for improving the health status of pigs with ETEC-associated diarrhoea.

\section{Acknowledgements}

The present study was supported financially by the Irish Research Council for Science, Engineering and Technology (IRCSET) and BioAtlantis Limited. The IRCSET and BioAtlantis Limited had no role in the design or analysis of the study or in the writing of this article.

The authors' contributions are as follows: G. H. wrote the manuscript, collected the samples and carried out the laboratory analysis; J. V. O'. D. was the principal investigator responsible for the design of the experiment, supervision of the data collection and statistical analysis and correction of the manuscript; T. S. designed the study and corrected the manuscript; C. J. O'. S. and D. N. D. contributed to the data collection and laboratory collection. All authors approved the final version of the manuscript.

None of the authors had a financial or personal conflict of interest in relation to the present study.

\section{References}

1. Nagy B \& Fekete PZ (1999) Enterotoxigenic Escherichia coli (ETEC) in farm animals. Vet Res 30, 259-284.

2. Francis DH (2002) Enterotoxigenic Escherichia coli infection in pigs and its diagnosis. J Swine Health Prod 10, 171-175.

3. Madec F, Bridoux N, Bounaix S, et al. (2000) Experimental models of porcine post-weaning colibacillosis and their relationship to post-weaning diarrhoea and digestive disorders as encountered in the field. Vet Microbiol $\mathbf{7 2}$, $295-310$.

4. Fairbrother JM, Nadeau E \& Gyles CL (2005) Escherichia coli in postweaning diarrhea in pigs: an update on bacterial types, pathogenesis, and prevention strategies. Anim Health Res Rev 6, 17-39.

5. Carstensen L, Ersbøll AK, Jensen KH, et al. (2005) Escherichia coli post-weaning diarrhoea occurrence in piglets with monitored exposure to creep feed. Vet Microbiol 110, 113-123.

6. Lallès JP, Bosi P, Smidt H, et al. (2007) Weaning - a challenge to gut physiologists. Livest Sci 108, 82-93.

7. Pluske JR, Hampson DJ \& Williams IH (1997) Factors influencing the structure and function of the small intestine in the weaned pig: a review. Livest Prod Sci 51, 215-236.

8. Lallès JP, Boudry G, Favier C, et al. (2004) Gut function and dysfunction in young pigs: physiology. Anim Res 53, 301-316.

9. Casewell M, Friis C, Marco E, et al. (2003) The European ban on growth-promoting antibiotics and emerging consequences for human and animal health. J Antimicrob Chemother 52, 159-161.

10. Pierce KM, Sweeney T, Brophy PO, et al. (2005) Dietary manipulation post weaning to improve piglet performance and gastro-intestinal health. Anim Sci 81, 347-356.

11. McDonnell P, Figat S \& O'Doherty JV (2010) The effect of dietary laminarin and fucoidan in the diet of the weanling piglet on performance, selected faecal microbial populations and volatile fatty acid concentrations. Animal 4, 579-585.

12. Walsh AM, Sweeney T, O'Shea CJ, et al. (2013) Effect of dietary laminarin and fucoidan on selected microbiota, intestinal morphology and immune status of the newly weaned pig. Br J Nutr 110, 1630-1638.

13. Heim G, Walsh AM, Sweeney T, et al. (2014) Effect of seaweed derived laminarin and fucoidan, and zinc oxide on gut morphology, nutrient transporters, nutrient digestibility, growth performance and selected microbial populations in weaned pigs. Br J Nutr 111, 1577-1585.

14. Leonard SG, Sweeney T, Bahar B, et al. (2011) Effects of dietary seaweed extract supplementation in sows and postweaned pigs on performance, intestinal morphology, intestinal microflora and immune status. Br J Nutr 106, 688-699.

15. Lynch MB, Sweeney T, Callan JJ, et al. (2009) The effect of dietary Laminaria-derived laminarin and fucoidan on nutrient digestibility, nitrogen utilisation, intestinal microflora 
and volatile fatty acid concentration in pigs. J Sci Food Agric 90, 430-437.

16. NRC (1998) Nutrient Requirements of Swine, 10th ed. Washington, DC: National Academic Press.

17. Zhang L, Xu YQ, Liu HY, et al. (2010) Evaluation of Lactobacillus rhamnosus GG using an Escherichia coli K88 model of piglet diarrhoea: effects on diarrhoea incidence, faecal microflora and immune responses. Vet Microbiol 141, 142-148.

18. Pierce KM, Callan JJ, McCarthy P, et al. (2005) Performance of weanling pigs offered low or high lactose diets supplemented with avilamycin or inulin. Anim Sci 80, 313-318.

19. Nataro JP, Deng Y \& Cookson S (1995) Heterogeneity of enteroaggregative Escherichia coli virulence demonstrated in volunteers. $J$ Infect Dis 171, 465.

20. Usov AI, Smirnova GP \& Klochkova NG (2001) Polysaccharides of algae: 55. Polysaccharide composition of several brown algae from Kamchatka. Russ J Bioorg Chem 27, 395-399.

21. O'Shea CJ, Sweeney T, Bahar B, et al. (2012) Indices of gastrointestinal fermentation and manure emissions of growingfinishing pigs as influenced through singular or combined consumption of Lactobacillus plantarum and inulin. J Anim Sci 90, 3848-3857.

22. Lee C, Kim J, Shin SG, et al. (2006) Absolute and relative qPCR quantification of plasmid copy number in Escherichia coli. J Biotechnol 123, 273-280.

23. Liu P, Piao XS, Thacker PA, et al. (2010) Chito-oligosaccharide reduces diarrhea incidence and attenuates the immune response of weaned pigs challenged with Escherichia coli K88. J Anim Sci 88, 3871-3879.

24. Leonard SG, Sweeney T, Bahar B, et al. (2012) Effect of maternal seaweed extract supplementation on suckling piglet growth, humoral immunity, selected microflora, and immune response after an ex vivo lipopolysaccharide challenge. J Anim Sci 90, 505-514.

25. Smith AG, O'Doherty JV, Reilly P, et al. (2011) The effects of laminarin derived from Laminaria digitata on measurements of gut health: selected bacterial populations, intestinal fermentation, mucin gene expression and cytokine gene expression in the pig. BrJ Nutr 105, 669-677.

26. Ryan MT, Collins CB, O'Doherty JV, et al. (2010) Selection of stable reference genes for quantitative real-time PCR in porcine gastrointestinal tissues. Livest Sci 133, 42-44.

27. Statistical Analysis Systems Institute (1985) Statistical Analysis Systems, 6.12 ed. Cary, NC: SAS Institute, Inc.

28. Littell RC, Henry PR \& Ammerman CB (1998) Statistical analysis of repeated measures data using SAS procedures. J Anim Sci 76, 1216-1231.

29. Meredith MJ (1995) Pigs breeding and infertility. In Animal Breeding and Infertility, pp. 278-353 [MJ Meredith, editor]. Bodmin: Blackwell Science.

30. Chau GP, Colllier CT, Welsh TH, et al. (2008) $\beta-1-3-G l u c a n$ effect on sow antibody production and passive immunization of the piglet. J Anim Vet Adv 7, 413-417.

31. Melin L, Mattsson S, Katouli M, et al. (2004) Development of postweaning diarrhoea in piglets. Relation to presence of Escherichia coli strains and rotavirus. J Vet Med B Infect Dis Vet Public Health 51, 12-22.

32. Li J, Li DF, Xing JJ, et al. (2006) Effects of $\beta$-glucans extracted from Saccharomyces cerevisiae on growth performance, and immunological and somatotropic responses of pigs challenged with Escherichia coli lipopolysaccharide. J Anim Sci 84, 2374-2381.
33. Leonard SG, Sweeney T, Bahar B, et al. (2010) Effect of maternal fish oil and seaweed extract supplementation on colostrum and milk composition, humoral immune response, and performance of suckled piglets. J Anim Sci 88, 2988-2997.

34. Owusu-Asiedu A, Nyachoti CM \& Marquardt RR (2003) Response of early-weaned pigs to an enterotoxigenic Escherichia coli (K88) challenge when fed diets containing spray-dried porcine plasma or pea protein isolate plus egg yolk antibody, zinc oxide, fumaric acid, or antibiotic. J Anim Sci 81, 1790-1798.

35. Montagne L, Pluske JR \& Hampson DJ (2003) A review of interactions between dietary fibre and the intestinal mucosa, and their consequences on digestive health in young nonruminant animals. Anim Feed Sci Technol 108, 95-117.

36. Nataro JP \& Kaper JB (1998) Diarrheagenic Escherichia coli. Clin Microbiol Rev 11, 142-201.

37. Yang KM, Jiang ZY, Zheng CT, et al. (2014) Effect of Lactobacillus plantarum on diarrhea and intestinal barrier function of young piglets challenged with enterotoxigenic Escherichia coli K88. J Anim Sci 92, 1496-1503.

38. Berberov EM, Zhou Y, Francis DH, et al. (2004) Relative importance of heat-labile enterotoxin in the causation of severe diarrheal disease in the gnotobiotic piglet model by a strain of enterotoxigenic Escherichia coli that produces multiple enterotoxins. Infect Immun 72, 3814-3924.

39. Girard F, Oswald IP, Taranu I, et al. (2005) Host immune status influences the development of attaching and effacing lesions in weaned pigs. Infect Immun 73, 5514-5523.

40. Pavlova B, Volf J, Alexa P, et al. (2008) Cytokine mRNA expression in porcine cell lines stimulated by enterotoxigenic Escherichia coli. Vet Microbiol 132, 105-110.

41. Takanashi N, Tomosada Y, Villena J, et al. (2013) Advanced application of bovine intestinal epithelial cell line for evaluating regulatory effect of lactobacilli against heat-killed enterotoxigenic Escherichia coli-mediated inflammation. BMC Microbiol 13, 54

42. Rice PJ, Adams EL, Ozment-Skelton T, et al. (2005) Orally delivered and gastrointestinal absorption of soluble glucans stimulate increased resistance to infectious challenge. J Pharmacol Exp Ther 314, 1079-1086.

43. Xiao Z, Trincado CA \& Murtaugh MPB (2004) Glucan enhancement of $\mathrm{T}$ cell IFN- $\gamma$ response in swine. Vet Immunol Immunopathol 102, 315-320.

44. Brown GD \& Gordon S (2005) Immune recognition of fungal $\beta$-glucans. Cell Microbiol 7, 471-479.

45. Chaung HC, Huang TC, Yu JH, et al. (2009) Immunomodulatory effects of $\beta$-glucans on porcine aveolar macrophages and bone marrow haematopoietic cell-derived dendritic cells. Vet Immunol Immunopathol 131, 147-157.

46. Sauvant D, Perez J-M \& Tran G (editors) (2004) Tables of Composition and Nutritional Value of Feed Materials. Pigs, Poultry, Cattle, Sheep, Goats, Rabbits, Horses, Fish. Wageningen: Wageningen Academic Publishers.

47. Zhang W, Zhao M, Ruesch L, et al. (2007) Prevalence of virulence genes in Escherichia coli strains recently isolated from young pigs with diarrhea in the US. Vet Microbiol $\mathbf{1 2 3}$ $145-152$

48. Metzler-Zebeli BU, Hooda S, Pieper R, et al. (2010) Nonstarch polysaccharides modulate bacterial microbiota, pathways for butyrate production, and abundance of pathogenic Escherichia coli in the pig gastrointestinal tract. Appl Environ Microbiol 76, 3692-3701. 